Piotr Banasik*, Marcin Ligas*, Jacek Kudrys*

\title{
Analysis of the Local HiL (Nowa Huta) Coordinate System for a Coordinate Transformation to the PL-2000**
}

\section{Introduction}

Local planar coordinate systems are used in geodesy for small areas. A sphere or a plane is the reference surface in such systems. A planar image of the reference surface in Cartesian system XOY is obtained as a result of cartographic projection of this surface onto a plane after adoption of local parameters of image position (a plane) with respect to the original (a sphere or a plane). In local systems that are used in areas with a spatial extent of a few kilometers, it is possible to adopt a plane as the surface of the original and image at the same time. In this way the need for a projection is eliminated.

Placing the plane of a local system on the surface of terrain allows for the direct use of results of field measurements (angular and linear) to calculate the coordinates of points in this system. The advantage of such a developed local system is limitation to minimum the computations associated with reductions and corrections due to a cartographic projection. For this reason, in the past, local plane coordinate systems were created for mapping and surveying services in urban areas or large industrial plants. Coordinates of a local system were often determined on the basis of pre-existing local or national systems within a given area (e.g. cadastral) [12]. As a result, it was possible to use already existing surveying materials [1]. It is estimated that since the 50s of the last century there have been established several hundred of such local systems on the territory of Poland.

Most of them survived to the end of the twentieth century, creating more than 100 enclaves on the background of the current national coordinate system [2]. In many cases, as a result of surveying works carried out in the local system there have been gathered considerable surveying and mapping resources.

* AGH University of Science and Technology, Faculty of Mining Surveying and Environmental Engineering, Krakow, Poland

** Developed within the framework of the statutory research No. 11.11.150.006 
Regulations of the National Spatial Reference System caused that local municipal systems had to be replaced by the current, national coordinate system [8,9]. Surveying and mapping materials produced in those systems have been transformed to the current national system, using different methods $[1,4,6]$.

Local coordinate systems, operating within large industrial plants lived the longest. An example of such the system is a plane coordinate system, designed for the construction and operation of the steel plant, known as Vladimir Lenin Steelworks, and later as Tadeusz Sendzimir Steelworks (now owned by ArcelorMittal Poland SA).

The Steelworks was created in the 50s of the last century within the area of Mogila village near Krakow (today, the district of Krakow-Nowa Huta). Plane coordinate system, so called Lviv cadastral system, which included the western part of Galicia, including Cracow area [1] functioned in this area since the mid-nineteenth century.

Reorganization of the Steelworks that has been implemented for the last several years caused that a large part of the area of Steelworks was transferred to the city. Therefore, it was necessary to incorporate the existing there control network to the municipal network and transformation of surveying and mapping materials from the HiL system to the current national system PL-2000.

This study describes steps involved in creating this local coordinate system and the resulting properties of the system. Also, the adopted way of transformation from the local system to the national one has been presented.

\section{Characteristic of Local Coordinate System (HiL)}

The first surveying works related to the planned construction of Steelworks in Nowa Huta were initiated in April 1949 [5]. The purpose of topographic surveys was to develop appropriate maps at scales from 1:500 to 1:5000, for the area of app. 900 ha.

In the measurements, existing national control network including the closest points of triangulation network with their coordinates in Lviv cadastral system and leveling network in Amsterdam datum (1926-1937) were used. At the same time it was decided that a distinct, local plane coordinate system XY will be developed for the Steelworks. The basis for this system was to be a geodetic quadrilateral with triangulation points at the vertices and own linear base (Fig. 1).

The HiL system was to be implemented on a plane running at an average ground level, without the use of cartographic projection.

This method of implementation eliminated the need for introducing projection corrections or reduction of measurements onto the reference surface in the future.

Consequently, within the present Steelworks area points of a geodetic quadrilateral have been selected and numbered I-IV, adapting a point of existing triangulation 
network (no 195) (Fig. 2). Points I-III were built up with triangulation signals (of $3 \mathrm{~m}$ height), point IV was built up with a triangulation tower (of $15 \mathrm{~m}$ height). Building up with signals assured the mutual visibility of quadrilateral vertices and also visibility to the closest points of triangulation network to which the quadrilateral was tied (Tab. 1). The triangulation tower at point IV provided visibility to more distant tie triangulation points.

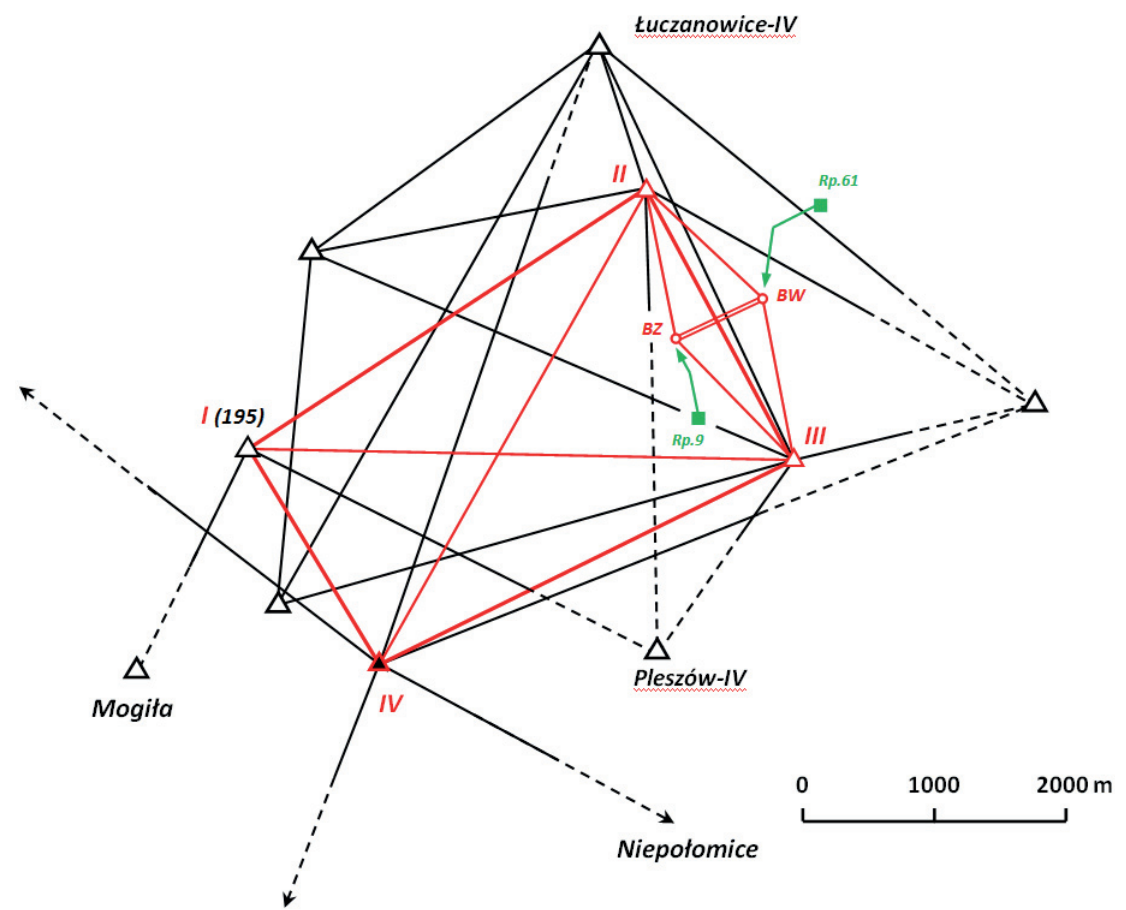

Fig. 1. Sketch of horizontal (black) and vertical (green) tie of the quadrilateral I-IV in the area of the Steelworks

Table 1. Cadastral coordinates of triangulation network points used for tying the geodetic quadrilateral

\begin{tabular}{|l|c|c|c||}
\hline \multicolumn{1}{|c|}{ Name } & Class & $X_{\mathrm{K}}[\mathrm{m}]$ & $Y_{\mathrm{K}}[\mathrm{m}]$ \\
\hline \hline Batowice & I & -35942.16 & 288975.03 \\
\hline Bogucice & I & -24534.91 & 286020.67 \\
\hline Grębałów & IV & -34087.19 & 284015.25 \\
\hline Łuczanowice & IV & -36609.17 & 281841.81 \\
\hline Niepołomice & I & -27582.33 & 274942.48 \\
\hline Pleszów & IV & -32036.29 & 281279.82 \\
\hline Ruszcza & III & -33963.47 & 278452.60 \\
\hline Wanda & I & -32299.37 & 284184.23 \\
\hline 195 & III & -33470.38 & 284422.85 \\
\hline
\end{tabular}




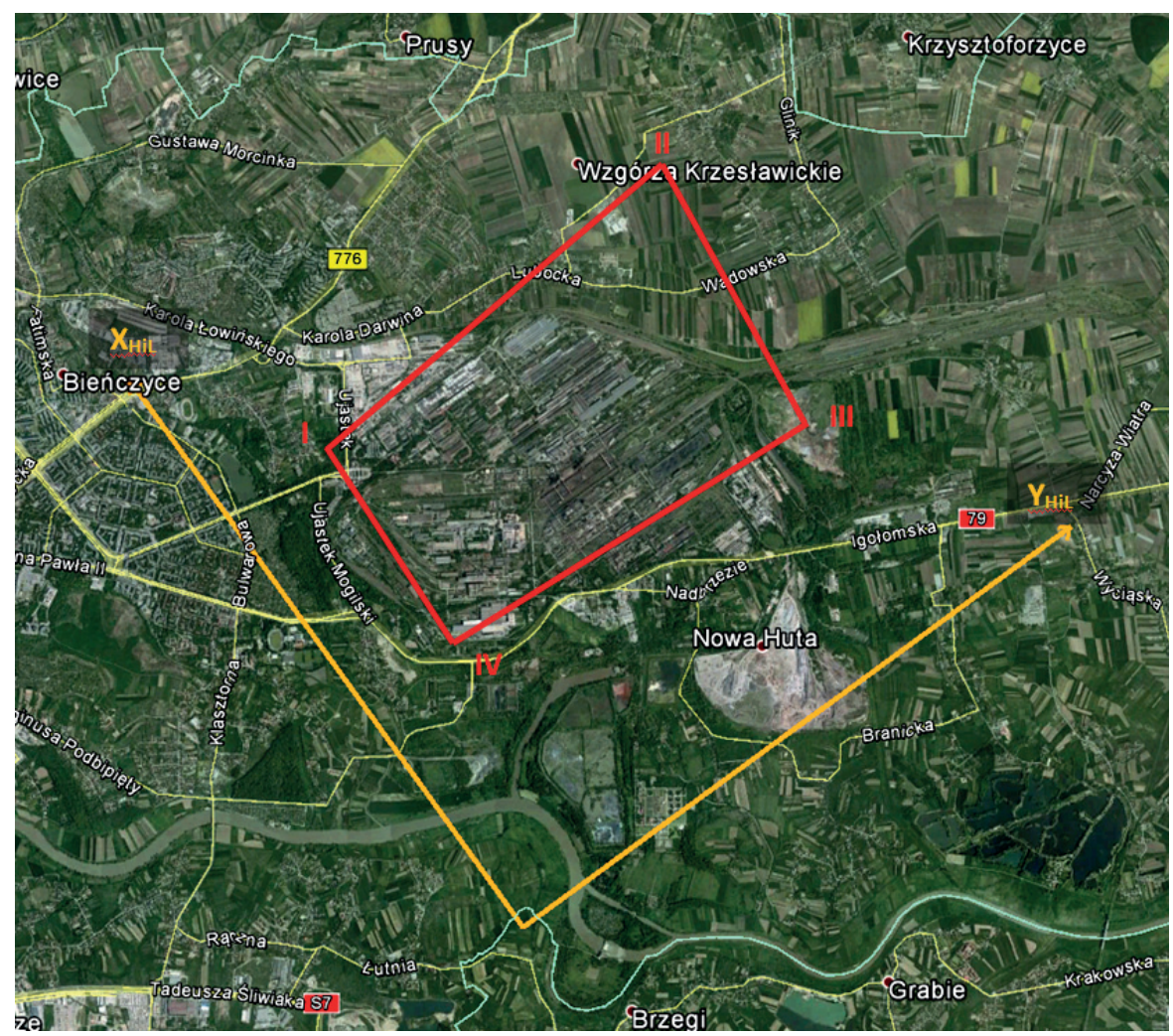

Fig. 2. Location of the quadrilateral and axes of HiL system against the contemporary topography in the area of the Steelworks

In order to tie the quadrilateral the cadastral coordinates $\left(\mathrm{X}_{\mathrm{K}^{\prime}} \mathrm{Y}_{\mathrm{K}}\right)$ (Lviv system) of the above mentioned triangulation points were used. Lengths of sides of the quadrilateral were equal to $d_{\mathrm{I}-\mathrm{II}}=3755 \mathrm{~m}, d_{\mathrm{II}-\mathrm{III}}=2552 \mathrm{~m}, d_{\mathrm{III}-\mathrm{IV}}=3509 \mathrm{~m}, d_{\mathrm{IV}-\mathrm{I}}=1978 \mathrm{~m}$. Horizontal angles were measured by directional method. Linear base of the quadrilateral was created on the eastern side II-III of the quadrilateral (Fig. 1). The baseline runs in the east-west direction in the azimuth of approx. $60^{\circ}$, on a terrain with the slope not exceeding 1/1000. The endpoints of the baseline were denoted as: western - BZ and eastern - BW. These points have been permanently stabilized (3-stage stabilization, the depth of the lower mark $3 \mathrm{~m}$ ). Measurement of the length of the baseline was carried out twice, using Jaederin's wire, with accuracy required for precise measurements. Points of the baseline were tied to the benchmarks of vertical control (Amsterdam vertical datum 1926-1937) by means of differential leveling; from west to the benchmark Rp Nr $9\left(H_{9}=214.105 \mathrm{~m}\right)$, from east to the benchmark $\operatorname{Rp} \mathrm{Nr} 61$ $\left(H_{61}=221.008 \mathrm{~m}\right)$ (Fig. 1).

Heights of baseline points centers were equal to: $H_{\mathrm{BZ}}=219.46 \mathrm{~m}\left(\varphi=50^{\circ} 05.5^{\prime}\right)$, $H_{\mathrm{BW}}=219.78 \mathrm{~m}\left(\varphi=50^{\circ} 05.7^{\prime}\right)$. 
The length of the baseline was reduced to the average height of terrain $H_{t}=220 \mathrm{~m}$. After entering appropriate reductions and corrections the length of the baseline on this level was equal to $D_{t}=719.860 \mathrm{~m}\left(m_{0}= \pm 0.6 \mathrm{~mm}\right)$. This length of the baseline was adopted for further computations (solution of triangles) and at the same time the linear scale of the future local system and the position of the plane of this system (on the average terrain) were set.

Calculation of coordinates of the vertices of the quadrilateral was carried out in several stages, passing through intermediate coordinate systems:

1) In coordinates of the cadastral system (Lviv) $X_{K^{\prime}} Y_{K}$ :

a) in the so called S1 system: in reference to existing triangulation points, coordinates of the point I were adopted from the existing triangulation, coordinates of the points II-IV through angular intersections to the neighboring points of triangulation (Fig. 1). In this way, cadastral coordinates of quadrilateral's vertices were obtained (Tab. 2);

Table 2. Coordinates of the quadrilateral in S1 system

\begin{tabular}{||c|c|c||}
\hline \hline Point & $X_{\mathrm{K}-\mathrm{S1}}[\mathrm{m}]$ & $Y_{\mathrm{K}-\mathrm{S1}}[\mathrm{m}]$ \\
\hline \hline I & -33470.38 & 284422.85 \\
\hline II & -35770.40 & 281453.92 \\
\hline III & -33485.24 & 280315.99 \\
\hline IV & -31786.07 & 283386.29 \\
\hline
\end{tabular}

b) in the so called S2 system:

- system $\mathrm{S2}_{\text {Base }}$ : cadastral coordinates with the scale from the baseline BZ-BW while maintaining the point I fixed,

- the coordinates were transformed from $\mathrm{S2}_{\text {Base }}$ system to $\mathrm{S} 1$ system (by Weigel's method [11]) creating the final version of coordinates in S2 system (Tab. 3).

Table 3. Coordinates of the quadrilateral in $\mathrm{S} 2_{\text {Base }}$ and $\mathrm{S} 2$ systems

\begin{tabular}{|c|c|c|c|c||}
\hline Point & $X_{\mathrm{K}-52 \text { Base }}[\mathrm{m}]$ & $Y_{\mathrm{K}-\mathrm{S} 2 \text { Base }}[\mathrm{m}]$ & $X_{\mathrm{K}-\mathrm{S2}}[\mathrm{m}]$ & $Y_{\mathrm{K}-\mathrm{S2}}[\mathrm{m}]$ \\
\hline \hline I & -33470.38 & 284422.85 & -33470.472 & 284422.501 \\
\hline II & -35770.095 & 281454.486 & -35770.097 & 281454.067 \\
\hline III & -33485.311 & 280316.611 & -33485.278 & 280316.261 \\
\hline IV & -31786.197 & 283386.451 & -31786.258 & 283386.153 \\
\hline
\end{tabular}

2) In the coordinates of the local HiL system:

S2 system was transformed to the local HiL system (named "working") by means of a rigid body transformation, adopting translations as $\left(X_{\mathrm{K}}=33406.00 \mathrm{~m}, Y_{\mathrm{K}}=-282053.00 \mathrm{~m}\right)$, a rotation angle as $\left(33^{\circ}\right)$ and a centroid in the "working" system as $\left(X_{\mathrm{B}}=3000.00 \mathrm{~m}, Y_{\mathrm{B}}=3000.00 \mathrm{~m}\right)$ (Tab. 4). 
Table 4. Coordinates of the quadrilateral in the HiL system

\begin{tabular}{|c|c|c||}
\hline Point & $X_{\text {HiL }}[\mathrm{m}]$ & $Y_{\text {HiL }}[\mathrm{m}]$ \\
\hline \hline I & 4344.590 & 1047.882 \\
\hline II & 4656.495 & 4789.882 \\
\hline III & 2120.591 & 4499.729 \\
\hline IV & 2367.653 & 999.749 \\
\hline
\end{tabular}

Points of the quadrilateral in coordinates of the HiL system constituted then the basis for the development of a control network within the area of Steelworks in this coordinate system. The above works and calculation steps may be presented by means of a diagram (Fig. 3).

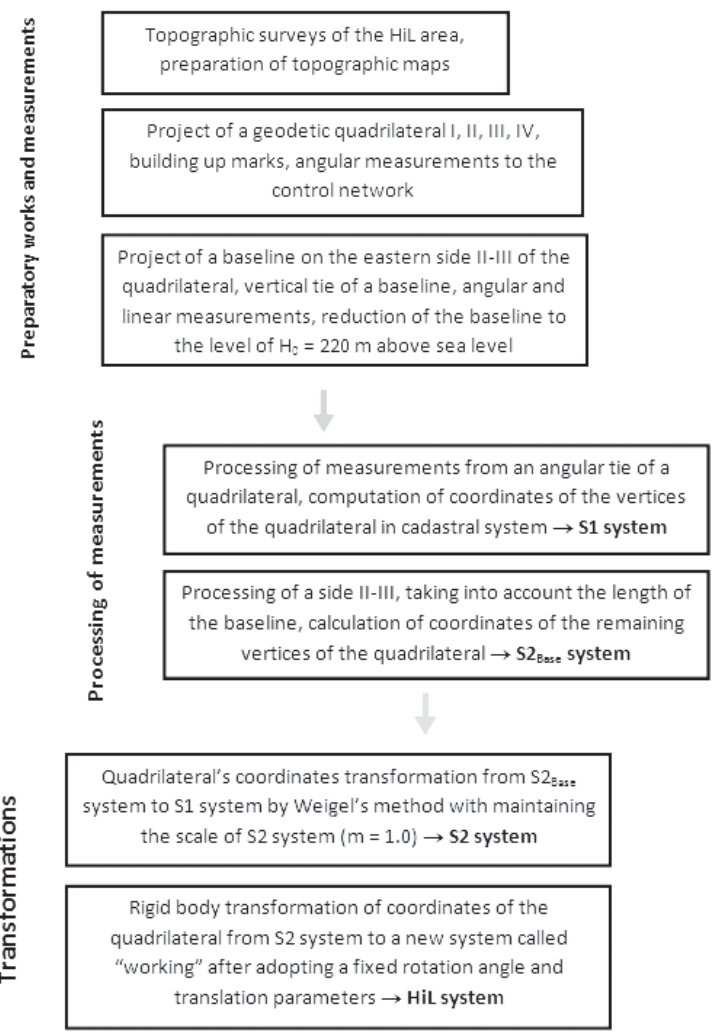

Fig. 3. Diagram of creation of the local HiL coordinate system

From the analysis of development of the HiL system it results that it is a coordinate system on the plane running at a height of $H=220 \mathrm{~m}$ above sea level. Coordinates of points in this system were calculated with reference to the cadastral system, but with a new scale obtained through the measured and reduced baseline. 


\section{Algorithm of Coordinate Transformation from the HiL to the PL-2000 System}

An analysis of the creation of the HiL system revealed that coordinates in this system are computed on the basis of field measurements directly on the plane of the system without the use of map projection. Accordingly, the variability of scale in this system that influences the choice of a transformation model from HiL $\rightarrow$ PL-2000 may be considered as zero. On the other hand, the variability of scale resulting from the map projection adopted in PL-2000 is minimal because of the small area. It ranges between $-2 \mathrm{~cm} / \mathrm{km}$ and $-3 \mathrm{~cm} / \mathrm{km}$ for the edge points of the transformation area. Considering both above factors, it may be assumed that a sufficient transforming polynomial between the above systems should be a polynomial of the first degree.

Such a polynomial in a general version allows for determining a scale that is dependent only on a direction (affine transformation, $m=m(\alpha)$ ). A special case is the Helmert transformation (conformal polynomial) with a fixed scale $(\mathrm{m}=\mathrm{const})$. Due to the directionality of the scale in the PL-2000 system (change of scale present in the direction of parallels) a better consistency between systems should be obtained by the affine transformation.

In accordance with the above conclusions, in order to convert coordinates from HiL system to PL-2000 system the affine model was used:

$$
\underbrace{\left[\begin{array}{c}
x_{i}^{\mathrm{PL}-2000} \\
y_{i}^{\mathrm{PL}-2000}
\end{array}\right]}_{\mathbf{x}}=\underbrace{\left[\begin{array}{l}
a_{0} \\
b_{0}
\end{array}\right]}_{\mathbf{T}}+\underbrace{\left[\begin{array}{ll}
a_{1} & a_{2} \\
b_{1} & b_{2}
\end{array}\right]}_{\mathbf{A}} \underbrace{\left[\begin{array}{l}
x_{i}^{\mathrm{HiL}}-x_{B}^{\mathrm{HiL}} \\
y_{i}^{\mathrm{HiL}}-y_{B}^{\mathrm{HiL}}
\end{array}\right]}_{\mathbf{x}}
$$

where:

$$
\begin{aligned}
& a_{0^{\prime}} a_{1^{\prime}} a_{2^{\prime}} b_{0^{\prime}} b_{1^{\prime}}, b_{2} \text { - coefficients of the affine transformation to be } \\
& \text { estimated, } \\
& x_{i}^{\mathrm{PL}-2000}, y_{i}^{\mathrm{PL}-2000}-\text { coordinates of points in the PL-2000 system } \\
& \text { (the secondary system), } \\
& x_{i}^{\mathrm{HiL}}, y_{i}^{\mathrm{HiL}} \text { - coordinates of points in the HiL system (the } \\
& \text { primary system), } \\
& x_{B}^{\mathrm{HiL}}=\frac{\sum_{i=1}^{n} x_{i}^{\mathrm{HiL}}}{n}, y_{B}^{\mathrm{HiL}}=\frac{\sum_{i=1}^{n} y_{i}^{\mathrm{HiL}}}{n}-\begin{array}{c}
\text { coordinates of the centroid/pole in the } \mathrm{HiL} \\
\text { system. }
\end{array}
\end{aligned}
$$

The transformation coefficients $a_{1}, a_{2}, b_{1}, b_{2}$ implicitly conceal geometric transformation parameters i.e.: a rotation angle $(\varphi)$, scales in directions of $x$ and $y$ axes $\left(s_{x}\right.$ i $\left.s_{y}\right)$ and a shear $\left(s_{x y}\right)$. Relations between the transformation coefficients and the geometric parameters may be expressed as [7]:

$$
\begin{aligned}
& a_{1}=s_{x} \cos \varphi-s_{x y} \sin \varphi, a_{2}=s_{x y} \cos \varphi-s_{y} \sin \varphi \\
& b_{1}=s_{x} \sin \varphi+s_{x y} \cos \varphi, b_{2}=s_{x y} \sin \varphi+s_{y} \cos \varphi
\end{aligned}
$$


With such adopted denotations the affine transformation model (1) can be rewritten as follows:

$$
\underbrace{\left[\begin{array}{c}
x_{i}^{\mathrm{PL}-2000} \\
y_{i}^{\mathrm{PL}-2000}
\end{array}\right]}_{\mathbf{X}}=\underbrace{\left[\begin{array}{l}
a_{0} \\
b_{0}
\end{array}\right]}_{\mathbf{T}}+\underbrace{\left[\begin{array}{cc}
\cos \varphi & -\sin \varphi \\
\sin \varphi & \cos \varphi
\end{array}\right]}_{\mathbf{R}} \underbrace{\left[\begin{array}{cc}
s_{x} & s_{x y} \\
s_{x y} & s_{y}
\end{array}\right]}_{\mathbf{S}} \underbrace{\left[\begin{array}{c}
x_{i}^{\mathrm{HiL}}-x_{B}^{\mathrm{HiL}} \\
y_{i}^{\mathrm{HiL}}-y_{B}^{\mathrm{HiL}}
\end{array}\right]}_{\mathbf{x}}
$$

By comparing (1) and (3) one obtains:

$$
\mathbf{A}=\mathbf{R S}
$$

where:

$\mathbf{R}$ - a rotation matrix (orthogonal matrix $\mathbf{R}^{\mathrm{T}} \mathbf{R}=\mathbf{I}$ ),

$\mathrm{S}$ - a deformation matrix (stretch and shear).

Formula (4) presents a polar decomposition of a square matrix A. In order to find the factors of the polar decomposition ( $\mathbf{R}$ and $\mathbf{S}$ matrices) of a matrix $\mathbf{A}$ in general case one may use a singular value decomposition (SVD) [3]:

$$
\mathbf{A}=\mathbf{U} \Sigma \mathbf{V}^{\mathrm{T}}
$$

where:

U, V - orthogonal matrices,

$\Sigma$ - diagonal matrix with non-negative values on the main diagonal.

Then the factors of the polar decomposition (4) may be expressed as:

$$
\mathbf{R}=\mathbf{U} \mathbf{V}^{\mathrm{T}} \text { and } \mathbf{S}=\mathbf{V} \Sigma \mathbf{V}^{\mathrm{T}}
$$

In the case of a $2 \times 2$ matrix (e.g.: a case of $2 \mathrm{D}$ affine transformation) a simple algorithm may be applied [10]:

$$
\mathbf{R}_{1}=\mathbf{A}+k_{1} \mathbf{A}_{1}
$$

where: $k_{1}=\operatorname{sgn}(\operatorname{det}(\mathbf{A})), \mathbf{A}_{1}=\left[\begin{array}{cc}b_{2} & -b_{1} \\ -a_{2} & a_{1}\end{array}\right]$

$$
\mathbf{R}=k_{2} \mathbf{R}_{1} \text { and } \mathbf{S}=\mathbf{R}^{\mathrm{T}} \mathbf{A}
$$

where $k_{2}$ - a scale factor that makes the columns of $\mathbf{R}$ unit vectors.

In the first stage a test affine transformation with 48 available common points was carried out. The distribution of points is not regular within the area of transformation. The points are located at the borders of the area, on the boundary of the city and the Steelworks (Fig. 4). 


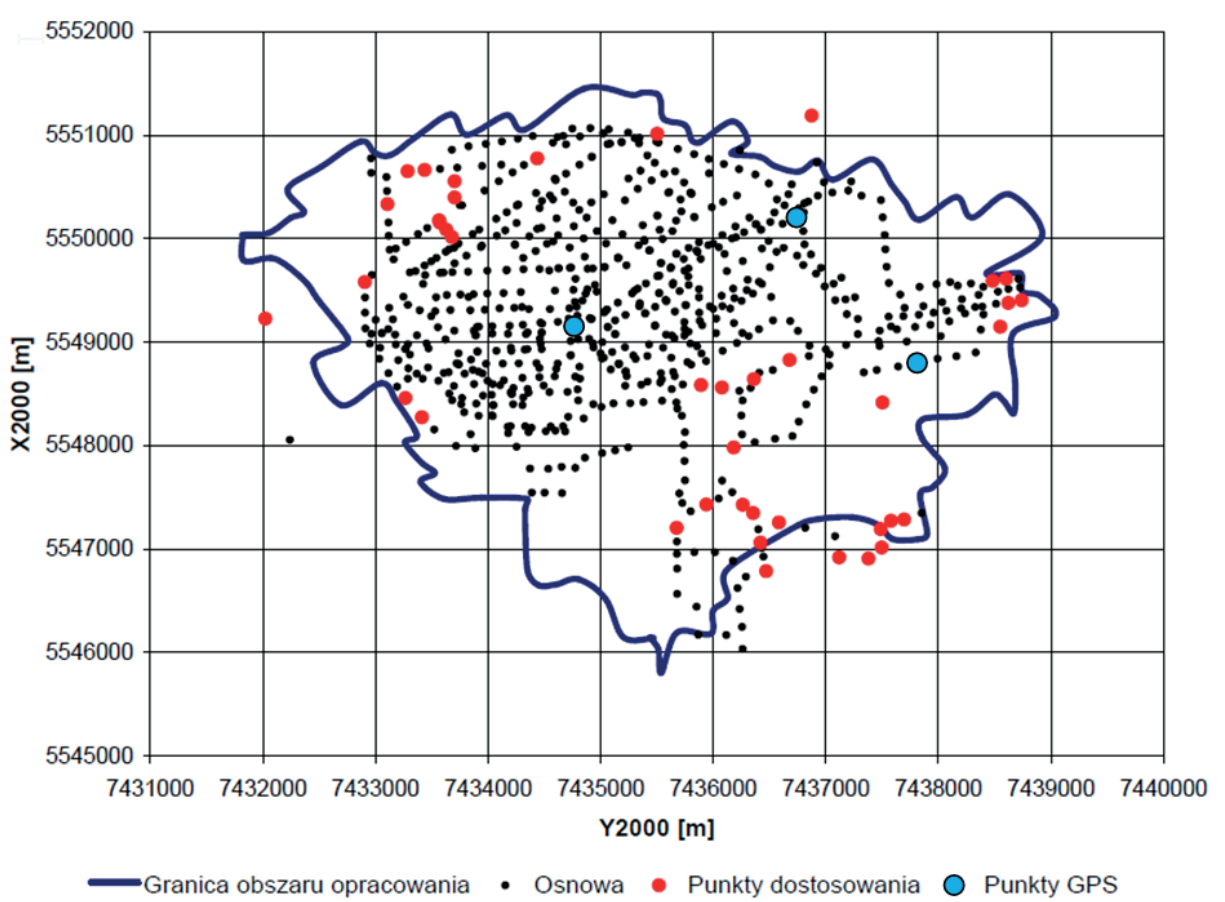

Fig. 4. Distribution of control network points, common points and GPS test points in the area of transformation from HiL to PL-2000

Uncertainty characteristics of test transformation revealed the necessity of elimination of some outlying points from the set of common points. Outlying points were removed sequentially (one by one) and each time a new transformation model was estimated with a full accuracy analysis. This sequential approach led to the elimination of 8 points considered as outliers and final parameters' estimation of the transformation model together with accuracy analysis based on 40 common points from the study area. For so selected common points the transformation parameters and appropriate indicators of accuracy were calculated.

To verify the correctness (actual accuracy of the transformation model) three control points measured by GPS technology (static method) were used (Fig. 4). The measurement was carried out in one observing session. Coordinates of points were determined with reference to the point KRA1 12218M002 of the fundamental national network, adopting its coordinates in PL-ETRF2000 at epoch 2011.0.

After processing of observation, coordinates characterized by an error of less than $1 \mathrm{~cm}$ after adjustment were obtained. By comparing the coordinates obtained from the transformation and direct measurement a position error of less than $3 \mathrm{~cm}$ was achieved. Therefore, the control (test) points were included in the group of common points. Subsequently, the new transformation parameters were computed (Tab. 5). 
Table 5. Transformation parameters (HiL to PL-2000) and accuracy characteristics

\begin{tabular}{|c|c|}
\hline \multicolumn{2}{|c|}{$\begin{array}{c}\text { Number of common points: } 43 \\
(86 \text { equations and 6 unknowns) }\end{array}$} \\
\hline Coordinates of a centroid in the primary system (HiL)
\end{tabular}

In the analyzed transformation between local HiL system and compulsory national PL-2000 system the geometric parameters of the affine transformation are as follows:

$$
\begin{gathered}
\varphi=324^{\circ} 40^{\prime} 43.8^{\prime \prime}, \\
s_{x}=0.9999398454, \\
s_{y}=0.9999285191, \\
s_{x y}=-0.0000061592 .
\end{gathered}
$$

The average scale of length in the above transformation is then equal to $s_{\text {Tr_HiL-PL-2000 }}=0.5\left(s_{x}+s_{y}\right)=0.999934$. This vale may be obtained independently by analyzing the position of planes of HiL and PL-2000 systems with respect to the GRS80 ellipsoid and the sea level (geoid) (Fig. 5). The plane of the HiL system runs on the level of $220 \mathrm{~m}$ above sea level, it is app. $260 \mathrm{~m}$ above the GRS ellipsoid (geoid undulation in this area is app. equal to $40 \mathrm{~m}$ ). Reduction of length from this plane onto the surface of the ellipsoid is carried with a scale factor $s_{\mathrm{HiL}-\mathrm{GRS} 80^{\prime}}$ equal to:

$$
S_{\text {HiL-GRS80 }}=R_{\mathrm{Ave}} /\left(R_{\mathrm{Ave}}+h\right)=6382000 / 6382260=0.9999593 \text {. }
$$




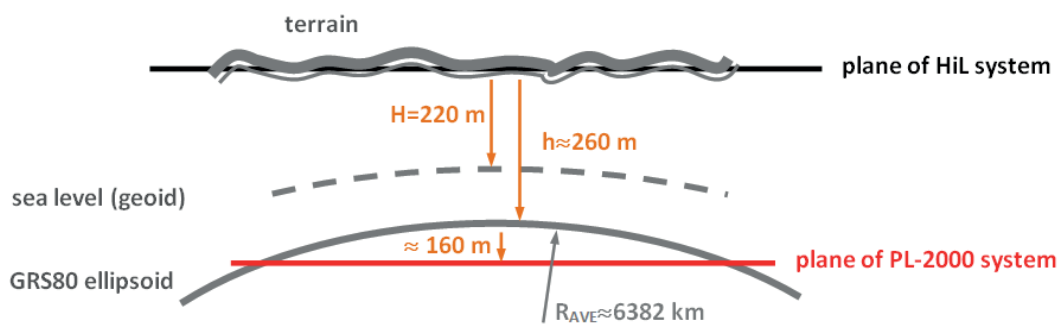

Fig. 5. Position of planes of HiL and PL-2000 systems relative to the surface of the GRS80 ellipsoid and sea level (geoid) in the area of the Steelworks

The so reduced plane of the HiL system should be then reduced to the level of the PL-2000 system's plane. Within the Steelworks area it runs below the surface of the ellipsoid. It is proven by the negative deformation in the PL-2000 system ranging from $-2.03 \mathrm{~cm} / \mathrm{km}$ (in the West of the Steelworks area) to $-3.09 \mathrm{~cm} / \mathrm{km}$ (in the East edges), on average $-2.56 \mathrm{~cm} / \mathrm{km}$ (app. $160 \mathrm{~m}$ below the surface of the ellipsoid). Replacing this deformation with a corresponding scale factor the value of $s_{\text {GRS80-PL-2000 }}=0.9999746$ will be obtained. Thus, the total scale between HiL and PL-2000 will be equal to $s_{\text {HiL-PL-2000 }}=s_{\text {HiL-GRS80 }} \times s_{\text {GRS80-PL-2000 }}=0.999934$.

The rotation angle (corresponds to the azimuth of the $\mathrm{X}$ axis of the HiL system with respect to the direction of $X$ axis of PL-2000 system (Fig. 2).

\section{Summary}

The HiL coordinate system was one of the examples of the local coordinate system, developed for the needs of a large industrial plant. For this purpose an existing triangulation network in the old cadastral system and leveling network in the pre-war system of Amsterdam were used.

Due to the small area where the system was to operate, a separate reference surface (sphere, ellipsoid) was given up, and a computation of coordinates was performed directly on the plane of the system based on the results of field measurements. Such a construction of the system in connection with a small extent of the area decided upon the choice of the affine transformation model to transform coordinates to the national PL-2000 system.

The accuracy of the transformation was verified by means of control points measured by the GPS technique.

Thanks to the developed transformation algorithm a detailed control network operating on the area of Steelworks was included to a detailed control network of Cracow and its points gained coordinates in the compulsory PL-2000 coordinate system. Coordinates obtained after the transformation were entered into the database of the control network for the city of Cracow maintained in the Municipal Documentation Centre for Geodesy and Cartography in Krakow. 


\section{References}

[1] Banasik P.: Analiza krakowskiego układu lokalnego pod katem jego transformacji do państwowych układów wspótrzędnych "1992" i "2000”. [in:] X sesja naukowo-techniczna: Aktualne problemy naukowe i techniczne prac geodezyjnych: Piwniczna 10-12.05.2001 r., AGH, Kraków 2001, pp. 6.2-6.10.

[2] Gajderowicz I.: Lokalne układy wspótrzędnych. Archiwum Fotogrametrii, Kartografii i Teledetekcji, vol. 13a, 2003, pp. 65-68.

[3] Golub G.H., van Loan C.F.: Matrix computations. The Johns Hopkins University Press, London 1996.

[4] Kadaj R.: Problematyka wyznaczenia formuł transformacyjnych pomiędzy układami lokalnymi a układem państwowym. [on-line:] http://geonet.net.pl/gfx/pliki/ uklady_new.doc [access: last visited 01.02.2016].

[5] Operaty z opracowań geodezyjnych realizowanych dla potrzeb budowy kombinatu metalurgicznego w Nowej Hucie w latach 1949-1951 [unpublished, provided by UM Kraków].

[6] Osada E.: Najlepsze dopasowanie - analiza metod transformacji mapy zasadniczej do układów 2000 i Kronsztad 1986 na przykładzie Wrocławia. Geodeta: Magazym Geoinformacyjny, nr 10, 2008, pp. 44-46.

[7] Osada E., Sergieieva K., Anigacz W.: Długości, pola lub kąty. Geodeta: Magazym Geoinformacyjny, nr 1, 2010, pp. 46-50.

[8] Rozporządzenie Rady Ministrów z 8 sierpnia 2000 r. w sprawie państwowego systemu odniesień przestrzennych. Dz.U. nr 70, poz. 821 [Journal of Laws, no. 70, item 821].

[9] Rozporządzenie Rady Ministrów z 15 października 2012 r. w sprawie państwowego systemu odniesień przestrzennych. Dz.U. 2012, poz. 1247 [Journal of Laws 2012, item 1247].

[10] Shoemake K., Duff T.: Matrix animation and polar decomposition. [in:] Proceedings of the conference on Graphics interface '92, Morgan Kaufmann Publishers Inc., San Francisco 1992, pp. 258-264.

[11] Weigel K.: O dostosowaniu tymczasowych sieci tryangulacyjnych do ostatecznej sieci tryangulacyjnej Państwa Polskiego. Archiwum Towarzystwa Naukowego we Lwowie, Wydział III Matematyczno-Przyrodniczy, t. 3, Lwów 1926.

[12] Włoczewski F.: Polska sieć triangulacji wypetniajacej i zagęszczającej. Przegląd Geodezyjny, r. 14, nr 6, 1959, pp. 209-213. 